\title{
ЦЕРКОВНА МУЗИКА КОМПОЗИТОРІВ УКРАЇНСЬКОЇ ДІАСПОРИ У ВІДРОДЖЕННІ НАЦІОНАЛЬНО-КУЛЬТУРНОЇ ТА РЕЛІГІЙНОЇ ІДЕНТИЧНОСТІ ПРАВОСЛАВНОЇ І ГРЕКО-КАТОЛИЦЬКОЇ ЦЕРКВИ В СУЧАСНІЙ УКРАЇНІ
}

\author{
Карась Г. В.
}

\section{ВСТУП}

Ідентичність $\epsilon$ невід'ємною складовою частиною глобалізованого світу. Ця тематика вже достатньо вивчена в науковому світі, а розроблені соиіокультурні аспекти дозволяють чіткіше осмислювати сучасні проблеми. Тематику ідентичності та суміжних з нею понять займалися зарубіжні (Е Гелнер ${ }^{1}$, М. Гібернау ${ }^{2}$, Е.Еріксон ${ }^{3}$, Е. Сміт ${ }^{4}$ ) та украйнські (С. Кияк, М. Козловець та Н. Ковтун ${ }^{6}$, Л. Нагорна ${ }^{7}$ ) вчені.

Хоч ідея ідентичності має тривалу історію, однак вона була актуалізована під час Другої світової війни американськонімецьким психологом Еріком Еріксоном. Ідентичність, на його думку, - ие «відповідність людини самій собі <..> твердий і особисто засвоєний образ себе у всьому багатстві відношення особистості до навколишнього світу, відчуття адекватності і стабільного оволодіння особистістю власного «я» незалежно від

${ }^{1}$ Гелнер Е. Нації та націоналізм. Націоналізм / пер. $з$ англ. Київ : Таксон, 2003. $300 \mathrm{c}$.

${ }^{2}$ Гібернау М. Ідентичність націй. Київ : Темпора, 2012. 304 с.

3 Эриксон Э. Идентичность: юность и кризис / пер. с англ.; общ. ред. И предисл. А.В. Толстых. 2-е изд. Москва : Флинта, 2006. 352 с.

4 Сміт Е. Культурні основи націй. Ієрархія, заповіт і республіка. Київ : Темпора, 2009. 312 с.

5 Кияк С. Ідентичність українського католицизму: генезис, проблеми, перспективи : монографія. Івано-Франківськ : Нова Зоря, 2006. 632 с.

6 Козловець М.А., Ковтун Н.М. Національна ідентичність в Україні в умовах глобалізації : монографія. Київ : ПАРАПАН, 2010. 348 с.

7 Нагорна Л.П. Регіональна ідентичність: український контекст. Київ : ІПіЕНД імені І.Ф. Кураса НАН України, 2008. 405 с. 
змін «я» і ситуації» ${ }^{8}$. Для політолога Монтсеррат Гібернау поняття ідентичності - це «інтерпретація Я, яка визначає, і в соціальному, і в психологічному аспектах, чим $\epsilon$ індивід i де він $\epsilon »{ }^{9}$. Тобто ідентичність має «багаторівневу структуру, котра пов'язана із трьома основними рівнями людської сутності: індивідуальним, особистісним і соціальним» 10 . В останньому, соціальному рівні «ідентичність має вигляд найбільш значущих політичних, культурних, релігійних та інших орієнтацій, якими детермінована мережа зв'язків людини із групами, інститутами, ідеями тощо» ${ }^{11}$.

Для України, яка третій десяток років розбудовує свою незалежну державу, актуальними є всі види ідентичності: національної, культурної і релігійної.

До основоположних елементів національної ідентичності М. Гібернау відносить «неперервність у часі й диференціацію від інших» 2 , де перше походить «від уявлення про націю як історично закорінену сутність, спроектовану в майбутнє» ${ }^{13}$, а друга $\epsilon$ «наслідком усвідомлення формування окремої громади, що має спільну культуру, минуле, символи і традиції, пов'язані з якоюсь обмеженою територією» ${ }^{14}$.

До ресурсів, що підтримують національну ідентичність у спільноті, Ентоні Сміт відносить «міфи про походження і міфи про етнічну обраність» ${ }^{15}$ і виводить чотири виміри національного існування: «спільноти, території, історії та долі» ${ }^{16}$. У М. Гібернау їх п'ять: «психологічний, культурний, територіальний, історичний і політичний» ${ }^{17}$.

8 Эриксон Э. Идентичность: юность и кризис / пер. с англ.; общ. ред. И предисл. А.В. Толстых. 2-е изд. Москва : Флинта, 2006. С. 12.

${ }_{9}^{9}$ Гібернау М. Ідентичність націй. Київ : Темпора, 2012. С. 19.

10 Козловець М.А., Ковтун Н.М. Національна ідентичність в Україні в умовах глобалізації: монографія. Київ: ПАРАПАН, 2010. С. 17.

11 Нагорна Л. П. Регіональна ідентичність: український контекст. Київ : ІПіЕНД імені І. Ф. Кураса НАН України, 2008. С. 34.

${ }^{12}$ Гібернау М. Ідентичність націй. Київ : Темпора, 2012. С. 19.

${ }^{13}$ Гібернау М. Ідентичність націй. Київ : Темпора, 2012. С. 19.

${ }^{14}$ Гібернау М. Ідентичність націй. Київ : Темпора, 2012. С. 20.

15 Сміт Е. Культурні основи націй. Ієрархія, заповіт і республіка. Київ : Темпора, 2009. С. 66.

16 Сміт Е. Культурні основи націй. Ієрархія, заповіт і республіка. Київ : Темпора, 2009. С. 66.

17 Гібернау М. Ідентичність націй. Київ : Темпора, 2012. С. 21. 
Людство складається з націй, як із формотворчої одиниці. Кожна людина у світі (за Е. Гелнером) реалізується «у власній культурі, а не в якійсь безкровній вселюдськості» ${ }^{18}$. У глобальному розумінні культурна ідентичність - це ідентифікація світовою спільнотою всіх культурних цінностей, надбань та традицій, набутих націями внаслідок свого культурного та історичного розвитку. Кожен елемент культурної ідентичності володіє специфічною національною ідентичністю того народу, 3 якого він походить і належить до певного історичного періоду. У вузькому розумінні культурна ідентичність - це «самовідчуття людини всередині певної культури» ${ }^{19}$. Тоді, коли індивід ототожнює себе із цінностями та установленими в певному суспільстві культурними моделями, і виникає культурна ідентичність.

Щодо релігійної ідентичності, то Святослав Кияк вважає, що вона $\epsilon$ «тим характерним еклезіологічним поняттям, в якому з усією повнотою реалізуються всі сутнісні форми буття церкви, тобто всі надії і завдання її як репрезентанта християнської релігії» ${ }^{20}$.

Історія української нації у XX столітті свідчить про тотальне придушення радянською тоталітарною системою всіх трьох окреслених видів ідентичності. Заборона релігії в атеїстичній державі СРСР нищила не тільки релігійну, а й національну та культурну ідентичність.

Вихід із підпілля УГКЦ, відновлення УАПЦ, створення УПЦ Київського патріархату в незалежній Україні сприяли становленню не тільки релігійної ідентичності, але національної і культурної.

Одним із засобів формування цих видів ідентичності $є$ церковна музика композиторів української діаспори.

Саме діаспора виконала компенсаторну функцію у збереженні такої музики, адже в атеїстичній державі про продукування і виконання її не могло бути й мови.

Такі видатні українські композитори діаспори, як Олександр Кошиць (1875-1944), Михайло Гайворонський (1892-1949), Андрій Гнатишин (1906-1995), Григорій Китастий (1907-1984), Мирон Федорів (1907-1996), Ігор Соневицький (1926-2006), Зіновій

18 Гелнер Е. Нації та націоналізм. Націоналізм / пер. 3 англ. Київ : Таксон, 2003. С. 205.

${ }^{19}$ Козловець М.А., Ковтун Н.М. Національна ідентичність в Україні в умовах глобалізації : монографія. Київ : ПАРАПАН, 2010. С. 40.

Кияк С. Ідентичність українського католицизму: генезис, проблеми, перспективи : монографія. Івано-Франківськ : Нова Зоря, 2006. С. 26. 
Лавришин (1943-2017), Роман Гурко (1962 р. н.), плідно працювали у цьому сегменті музичної культури. Ними створені як цілісні циклічні музичні форми (Літургії, панахиди, тощо), так і окремі духовні твори ${ }^{21}$.

Із перших років Незалежності в Україну повертається ця безцінна спадщина - пересилаються нотні видання, які побачили свят за кордоном, а згодом друкуються вже і в Україні як окремі видання, окремі церковні твори. Саме тиражування нотних видань прискорює поширення їх серед церковних хорів, викладачів хорової справи та диригування в навчальних закладах.

\section{1. Твори композиторів діаспори в репертуарі кафедральних та парафіяльних хорів української церкви}

Із часу проголошення Незалежності України твори композиторів української діаспори ввійшли до репертуару кафедральних та парафіяльних хорів української церкви (як греко-католицької, так і православної).

У перші роки Незалежності такої хорової літератури не було в Україні, оскільки в радянській атеїстичній державі церковна музику була заборонена. Для забезпечення Літургії та інших церковних відправ регенти спершу найчастіше використовували нотні збірники, які були надруковані в діаспорі музичним відділом Науково-Богословського інституту Української Православної Церкви в США під упорядкуванням Василя Завітневича ${ }^{22}$, регентом хору церкви св. Варвари у Відні, композитором Андрієм

21 Детальніше див.: Карась Г. Музична культура української діаспори у світовому часопросторі XX століття: монографія. Івано-Франківськ : Тіповіт, 2012. $1164 \mathrm{c}$.

${ }^{22}$ Велика Субота і Пасха: партитура / ред., упор. Василь Завітневич. Нью-Йорк : Науково-Богословський ін-т Української Православної Церкви в США, музичний відділ, 1964. 207 с.; Всеношна: партитура, част.1: Вечірня / [ред. і упор. В. Завітневича] / Науково-Богословський інститут Української Православної Церкви в США, Музичний відділ. Нью-Йорк, 1960. 264 с.; Всеношна: Партитура, част. 2: Утреня / [ред. і упор. В. Завітневича] / Науково-Богословський інститут Української Православної Церкви в США, Музичний відділ. Нью-Йорк, 1961. 267 c.; Збірник літургійних співів присвячений тисячоліттю Української православної церкви / зредагував і впорядкував Василь Завітневич. Бавнд Брук, Нью-Джерзі : Видання УПЦ в США, 1979. 467 с.; Співи на Літургії: Партитура / [ред. i упор. В. Завітневич] / Науково-Богословський інститут Української Православної Церкви в США, Музичний відділ. Нью-Йорк, 1963. 399 с.; Співи Постової Тріоді: Партитура / [ред. і упор. В. Завітневич] / Науково-Богословський інститут Української Православної Церкви в США, Музичний відділ, 2-ге вид. Бавнд-Брук, Нью-Джерзі, 1978. 196 с. 
Гнатишиним $^{23}$, композиторами Зеноном Лавришиним 3 Канади $^{24}$ і Мироном Федорівим із США ${ }^{25}$, видавцем Василем Трухлим $(\mathrm{CША})^{26}$, упорядниками Зіновієм Лиськом (США $)^{27}$, Степаном

${ }^{23}$ Гнатишин А. Богородиці на славу - Ukrainische Marienlieder: хорові твори a cappella. Відень, 1974. 41c. Рукопис.; Гнатишин А. Божественна літургія (Die Göttliche Liturgie): для триголосного хору a cappella: Kirchenslawisch. Deutsch, 1998. 141 с.; Гнатишин А. Молебень до Христа-Чоловіколюбця (Andacht zu Christus dem Menschenfreund) - для мішаного хору а capella. Відень. 6 с.; 20. Гнатишин А. Служба Божа: (Göttliche Liturgie unseres heiligen Vaters JOHANNES CHRISOSTOMOS) для мішаного хору а capella. Відень, 1965. 65 с. Рукопис.; Гнатишин А. Служба Божа - самолівкова; для мішаного хору а capella: в кінці автограф: “Цю українську (самоїлкову) Службу Божу опрацював я на бажання мого доброго Приятеля Юліана Позняка і його хору при церкві Св. Йосифа в Чікаго (США)”. Відень, 1985. 34 с. Рукопис.; Гнатишин А. Українські церковні пісні на всі свята для мішаного хору / передмова о. Софрон Мудрий, організатор видання. Відень - Рим, 1986. 113 с.

24 Лавришин 3. Служба Божа на сопран, альт і бас. Торонто: Накладом автора, 1978. 27 с.; Лавришин 3. Служба Божа. Літургія для мішаного хору. Торонто, 1988. 64 с. [Б-ка української духовної музики. У пам'ять 1000-ліття Хрещення Руси-України].

25 Федорів М. Велика Вечірня з Литією. У пам'ять 1000-ліття Хрещення Руси-України (988-1988) для мішаного хору. Філядельфія, 1986. 49 с.; Федорів М. Срусалимська утреня у Велику П'ятницю на мішаний хор. Чікаго, 1971. 48 с.; Федорів М. Срусалимська утреня (у Велику П'ятницю) на мішаний хор. 2-е вид. Філадельфія, 1982. 46 с.; Федорів М. Збірник літургічних співів Закарпатської Церкви Візантійського обряду для мішаного хору. Філядельфія, 1982. 108 с. [Із серії видань $з$ підготовчого періоду для відзначення 1000-ліття християнства Руси-України (988-1988)]; Федорів М. М. Обрядові співи української церкви Галицької Землі. ІІ ч. Літургійні співи. Філядельфія, ПА, 1983. 294 с.; 1989. 395 с.; Федорів М. Служба Божа F-dur для мішаного хору. Філядельфія, 1982. 30с. Федорів М. Служба Божа для мішаного хору in G-dur. Подана за українським народним наспівом. Чікаго: Вид-во Єпархії св. О. Николая, 1967. 35 с.; Федорів М. Українські релігійні пісні на хори мішані, чоловічі й жіночі. Ч.І. Шікаго: Видання О.О. Василіян, 1960. 52 с.; Федорів М. Українські релігійні пісні на хори мішані, чоловічі й жіночі,сольові й інструментальні. Ч. ІІ. Шікаго: Видання О.О. Василіян, 1960. 55 с.; Федорів М. Церковні співи на три однорідні голоси (жіночі або чоловічі). Філядельфія: Видання сс. Василіянок, 1986. 105 с.; Федорів М. Частини до Служби Божої та інше на мішаний хор. Видання оо. Василіан, 1991. 100 с. [Із серії видань 3 підготовчого періоду для відзначення Тисячоліття Хрещення Руси-України (988-1988)].

26 Літургія (скорочене видання) : збірка професора Івана Трухлого / ред. І видавець д-р Василь Трухлий. Чикаго: Фундація Катерини Здорик, 1991. 260 с.

${ }^{27}$ Кошиць Олександер. Релігійні твори / за ред. Зіновія Лиська. Нью-Йорк: УВАН у США, $1970.736 \mathrm{c}$. 
Чичулою (США) ${ }^{28}$, Андрієм Ситником (Австралія) ${ }^{29}$, Богданом Кушніром (США $)^{30}$, Капелою бандуристів ім. Тараса Шевченка $(\text { США })^{31}$.

Згодом розпочинається друк нотних видань композиторів діаспори в незалежній Україні. Їх можна поділити на два умовні види: а) видання творів одного композитора (Михайло Гайворонський ${ }^{32}$, Андрій Гнатишин ${ }^{33}$, Ігор Соневицький ${ }^{34}$, Григорій Китастий ${ }^{35}$, Мирон Федорів ${ }^{36}$ ); б) окремі твори композиторів діаспори у збірках духовних творів (найчастіше це твори Олександра Кошиця, Андрія Гнатишина, Михайла Гайворонського, Ігоря Соневицького) ${ }^{37}$. Ініціаторами цих видань, як правило, були

28 Вінчання / зібрав і до тексту української народної мови приробив С. Чичула. Чікаго, 1976. 12 с. [Кафедральний хор «Славута». Мистецький керівник Юрій Яримович]; Літургічні пісні для чоловічого хору / зібрав і до тексту в українській народній мові приробив Степан Чичула, 2-ге вид. Чикаго, 1984. 88 с.; Літургічні пісні для чоловічого хору, част. 2 / зібрав і до тексту в українській народній мові приробив Степан Чичула, 6-е поширене вид. Чикаго, 1984. 136 с.; Літургічні пісні. Мішаний хор. Різні композитори. Служба Божа. Додаткові пісні до Служби Божої. Чин Вінчання. Чин Похорону. Воскресна Утреня. Пісні на сцену. Принагідні пісні / зібрав і до тексту в українській народні мові приробив С. Чичула. 4-е, дещо змінене вид. Шикаго, 1979. 240 с.

29 Збірник Літургійних і Церковних пісен / упор. Андрій Ситник. Аделаїда, Австралія: В-во: Slavic Musoft, 1991. 94 с.

30 Літургії і Панахида на основі традиційних мотивів західніх українських земель на мішаний хор уложив Богдан Кушнір. [Детройт, США], [б. р.]. 138 с.

31 36. Літургія. Divine Liturgy. Капеля Бандуристів ім. Т. Шевченка (США). Нью-Йорк, 2003. 79 с.

32 Духовні композиції Михайла Гайворонського: навч.-метод. посібник / упоряд. А. Славич. Дрогобич : Посвіт, 2015.

${ }^{33}$ Гнатишин А. Хорові твори / ред.-упоряд. С. Дацюк. Дрогобич : Посвіт, 2010. 79 c.

${ }^{34}$ Соневицький І. Духовні твори. Львів : Спілка композиторів України, 1999. 108 с.; Соневицький I. Літургія g-moll. Соневицький I. Духовні твори. Львів : Спілка композиторів України, 1999. С. 5-48.

${ }^{35}$ Китастий Г. Служба Божа. Нотна збірка для мішаного хору. Київ, 2006. 56 с. [Бібліотека хору «Дзвони Подолу»].

${ }^{36}$ Федорів М. Церковні пісні для змішаного хору. І. Молебні пісні до Матері Божої. Львів : Вид-во Отців Василіян «Місіонер», 1995. 64 с.; Федорів М. Церковні пісні на мішаний хор. Репринтне видання. Львів, 2004. 36 с.

37 Благослови, душе моя, Господа: хорові твори 3 репертуару камерного хору «Кредо» кафедрального собору св. Воскресіння УГКЦ м. ІваноФранківська / упоряд Ж. Зваричук. Івано-Франківськ : Плай, 2010. 90 с.; Вибрані хорові твори українських композиторів для Служби Божої. 
практикуючі диригенти, регенти, викладачі вищих музичних навчальних закладів, які усвідомлювали потребу таких видань як навчально-методичного матеріалу для роботи зі студентами i як джерельну базу для практичної діяльності церковних хорів різних конфесій.

Архикатедральний хор собору св. Юра УГКЦу Львові (регент Надія Поворозник, викладач Львівського державного музичного училища ім. Станіслава Людкевича) до репертуару включив частини Служби Божої О.Кошиця («Заключна єктенія»), I. Соневицького («Херувимська», «Будь ім’я Господнє»), Р. Гурка (кілька єктеній, 103 псалом «Благослови, душе моя, Господа», «Блажен муж», «Будь ім'я Господнє») та паралітургійні твори О. Кошиця («Тіло Христове», «Восшел єси»), І. Соневицького («Під твою милість»), Р. Гурка («Світе тихий»).

Архисрейський камерний хор «Кредо» Катедрального собору св. Воскресіння УГКЦ в Івано-Франківську (регент - заслужений працівник культури України, кандидат мистецтвознавства, доцент Прикарпатського національного університету імені Василя Стефаника Жанна Зваричук) з перших років створення вводить у репертуар церковні твори композиторів діаспори, окремі 3 них записують на CD. Це частини із «Служби Божої» О. Кошиця («Сктенія велика», «Вхідне», «Святий Боже», «Алилуя», «Сктенія потрійна», «Тебе оспівуємо», «Достойно», «Благословен, хто йде»), М. Федоріва («Сктенія велика»), А. Гнатишина («Сктенія велика», «Перший антифон» (недільний), «Сктенія мала», «Слава... Єдинородний», «Вхідне», «Святий Боже», «Сктенія потрійна», «Сктенія благальна», «Отця і Сина...», «Вірую», «Милість миру», «Єктенія благальна», «Отче наш», «Благословен, хто йде», «Ми бачили світло істинне», «Богородице Діво»), Г. Китастого («Алилуя»), М. Федоріва («Алилуя»), І. Соневицького («Будь ім'я Господнє»), Р. Гурка («Богородице Діво, радуйся»), М. Федоріва («Воскресна Утреня»); паралітургійні твори: «Боже великий

3 репертуару камерного хору «Благовіст» / упоряд. 3.П. Яропуд, о. А. Федик. Кам'янець-Подільський: видавець П.П. Зволейко, 2017. 288 с.; Свята Літургія Івана Золотоустого: вибрані хорові твори українських композиторів для Служби Божої. 3 репертуару камерного хору «Кредо» / упоряд. о. Ю. Новицький, Ж. Зваричук. Івано-Франківськ : Нова Зоря, 2009. 180 с.; Херувимська пісня України та їі діаспори. Антологія / упоряд. Г. Куземська, Д. Редчук. Київ : КЖД «Софія», видання парафії св. Архистратига Михаїла, Київ (Пирогів), 2010. 516 с. 
єдиний» М. Лисенка в аранжуванні О. Кошиця, «Під твою милість» I. Соневицького в гармонізації Р. Демчишина, а також ряд творів із видання А. Гнатишина «Українські церковні пісні на всі свята для мішаного хору» (Відень-Рим,1986): «Йордан ріко», «Чути крики і гомін», «О, горе мені», «Воспойте согласно», «Взбранная діво», «Великодні дзвони», «Єрусалиме», «Согласно заспіваймо», «Господь вознесеся», «Царю небесний», «Заграйте дзвони», «Святий, Великий Володимире», «Преобразився на горі», «Станьмо нині», «Троне вишній», «Світло неба», «Вишні хори», «Славная днина», «Отче Николає», «О хто, хто Миколая любить», «Достойно єсть», «Вірую Господи». Ці твори хор виконує як під час Літургії, так і в концертних виступах в Україні та за їі кордоном.

\section{Архісрейський хор «Воскресіння" Рівненського Свято-} Воскресенського Кафедрального собору Украйнської Православноӥ Церкви (регент - заслужений діяч мистецтв України Олександр Тарасенко) за майже 30 років своєї творчої діяльності освоїв величезний репертуар (понад 500 зразків церковної, академічної духовної і світської музики), який виконує не тільки в Україні, а й багатьох країнах Європи на міжнародних конкурсах та фестивалях. Чільне місце в ньому займає хорова духовна спадщина Олександра Кошиця. На II Всеукраїнському хоровому конкурсі ім. Миколи Леонтовича (1993) хор виконує його «Достойно є» і стає лауреатом I ступеня ${ }^{38}$. Того ж року хор виступає 3 концертами в Баварії (Німеччина), виконуючи у т. ч. «О тебі радується» та «Достойно є» О. Кошиця. У грудні 2004 і 2006 років на Міжнародному фестивалі «Колядки по-сусідськи» у Кракові (Польща) хор співає «Що то за предиво» в обр. А. Гнатишина. Цей твір хор співає на фестивалі «Різдвяна псальма 2008» у Пщині (Польща). На Всепольському хоровому конкурсі хорів «Лігниця Кантат 2007» хор «Воскресіння» виступав як гість, виконуючи у т. ч. «О тебі радується» та «Милось мира» О. Кошиця. Ці твори були виконані хором на концерті духовної музики в м. Сандомеж $(\text { Польща) })^{39}$. Сва та Януш Війціки згадували, що стосунки, які нав'язали хористи з Рівного 3 прихожанами приходського костелу в одній із дільниць Яворжина, «для українсько-польських взаємин

38 Воскресіння. Хорова родина. Нариси 3 історії хорового мистецтва / упоряд. О. Тарасенко. Рівне : О. Зень, 2011. С. 47, 49.

39 Воскресіння. Хорова родина. Нариси 3 історії хорового мистецтва / упоряд. О. Тарасенко. Рівне : О. Зень, 2011. С. 85, 94. 
можуть зробити більше, ніж офіційні показові зустрічі... <..> Музика пом'якшує звичаї. Музика зближує і розмовляє мовою, що зрозуміла для всіх людей - мовою серця і любові» ${ }^{40}$.

Очоливши у 2005-2006 навчальному році студентський хор Національної музичної академії ім. П.І. Чайковського, Олександр Тарасенко взяв участь у мистецькій акції, присвяченій 130-річчю від дня народження одного 3 фундаторів української хорової школи Олександра Кошиця. На відкриття хорової асамблеї хор підготував 10-частинний цикл O. Кошиця «Релігійні канти та псальми українського народу». Це видання, яке побачило світ у 1920 році в києво-лейпцигському видавництві ${ }^{41}$, для О. Тарасенка передав iз Канади Петро Рута ${ }^{42}$. Надія Супрун-Яремко писала: «Пізнаючи цей твір О.Кошиця через істову роботу 3 великою студентською капелою, він відчував, як «ламає» генетичний код атеїстично налаштованої переважної більшості сучасних студентів. Адже музика кожного з 10 номерів складного твору розкриває щиру релігійність українців, яка закарбувалася в генетичній пам'яті багатьох минулих поколінь...» ${ }^{43}$. Оскільки проект відтворення рідкісного хорового твору О. Кошиця здійснювався під патронатом президента України, тому, крім прем'єрного виконання, був записаний на диск.

У репертуарі камерного хору «Благовіст» кафедрального собору Матері Божої Почайвської Украӥнської ГрекоКатолицької Церкви міста Кам'янець-Подільського (регент професор кафедри музичного мистецтва Кам'янець-Подільського національного університету імені Івана Огієнка Зіновій Яропуд) частини з Літургії М. Федоріва («Сктенія велика»), А. Гнатишина («Святий Боже»), О. Кошиця («Усі ті, що в Христа хрестилися», «І духові Твоєму», «Слава Тобі, Господи», «Єктенія Потрійна», «Свят, свят, свят», «Тебе оспівуємо», «Благословен, хто йде...», «Ми бачили світло істинне», «Боже великий єдиний» музика

40 Воскресіння. Хорова родина. Нариси 3 історії хорового мистецтва / упоряд. О. Тарасенко. Рівне : О. Зень, 2011. С. 221.

41 Релігійні канти та псальми українського народу: на мішаний хор / аранжував О. Кошиць. Київ; Ляйпціг : Українська накладня, Б. p. 30 с. Вид-во «Україна». Ч. 53.

42 Воскресіння. Хорова родина. Нариси 3 історії хорового мистецтва / упоряд. О. Тарасенко. Рівне : О. Зень, 2011. С. 24, 25.

43 Воскресіння. Хорова родина. Нариси 3 історії хорового мистецтва / упоряд. О. Тарасенко. Рівне : О. Зень, 2011. С. 25. 
M. Лисенка в аранжуванні О. Кошиця), M. Гайворонського (Алилуя), паралітургійні твори Євгена Ореста Садовського («O Ісусе»), М. Гайворонського («Молитовний кант») ${ }^{44}$.

Хор "Cantemus» церкви Царя Христа монастиря отців василіан з Івано-Франківська (регент - заслужений діяч мистецтв України, кандидат мистецтвознавства Ігор Дем'янець) активно пропагує творчість Андрія Гнатишина.

Отже, літургійні та паралітургійні твори композиторів української діаспори хорові колективи духовної музики виконують не тільки в церкві під час Служби Божої, а й у багаточисельних концертних виступах як в Україні, так і у всьому світі.

\section{2. Грамзаписи церковної музики композиторів діаспори хорами в Україні}

Важливою складовою частиною формування культурної, національної та релігійної ідентичностей є грамзаписи. Провідні церковні та світські хори України записують твори композиторів діаспори $з$ початку 1990-х. Одним із перших це зробив Архієрейський хор «Воскресіння» Рівненського Свято-Восресенського Кафедрального собору УПЦ (регент - О. Тарасенко). До аудіоальбому 1992 року було записано «Боже великий, єдиний» М. Лисенка в аранжуванні О. Кошиця, до аудіоальбомів 1993 та 1996 років - «О тебі радується» та «Достойно є» О. Кошиця ${ }^{45}$. Ці твори хор вносить до CD 1993, 1995 та 1998 років $^{46}$. До CD «3 нами Бог» записують колядку «Що то за предиво» в обробці А. Гнатишина.

До 2000-ліття Різдва Христового ансамбль солістів «Благовість» (диригент Мирослав Гулковський, художній керівник Тетяна Кумановська) із Києва записав CD духовної музики із серії «Золоті сторінки української музики» (1997). Серед записаних творів «Христос воскрес» А. Гнатишина ${ }^{47}$. Львівський камерний хор

44 Вибрані хорові твори українських композиторів для Служби Божої. 3 репертуару камерного хору «Благовіст» / упоряд. 3.П. Яропуд, О.А. Федик. Кам'янець-Подільський : видавець П.П. Зволейко, 2017. 288 с.

45 Воскресіння. Хорова родина. Нариси 3 історії хорового мистецтва / упоряд. О. Тарасенко. Рівне : О. Зень, 2011. С. 336, 337.

46 Воскресіння. Хорова родина. Нариси 3 історії хорового мистецтва / упоряд. О. Тарасенко. Рівне : О. Зень, 2011. С. 338.

47 До 2000-ліття Різдва Христового «Золоті сторінки української музики». Ансамбль солістів «Благовість». Духовна музика / диригент Мирослав Гулковський. Художній керівник Тетяна Кумановська. CD. 1997. 
«Gloria» (мистецький керівник і диригент Володимир Сивохіп) у 2002 році записав «Літургію» та «Панахиду» Ігоря Соневицького iз США ${ }^{48}$. Церковний хор «Видубичі» з Києва (регент Володимир Віняр, диригент Зеновій Паламар) у 2003 році випускає два CD: «Хваліть ім'я Господнє» ${ }^{49}$, до якого вносить канти А. Гнатишина («Ізбави од бід», «Що то за предиво») та «Літургію № 2» Р. Гурка 3 Канади ${ }^{50}$. Камерний хор «Дзвони Подолу» (диригент - Тарас Миронюк) записує «Службу Божу» Г. Китастого (2003) $)^{51}$. Камерний хор «Кредо» Катедрального собору св. Воскресіння УГКЦ в ІваноФранківську (регент - заслужений працівник культури України, кандидат мистецтвознавства, доцент Прикарпатського національного університету імені Василя Стефаника Жанна Зваричук) записав CD: «Благослови, душе моя, Господа» (початок 2000-х), до якого ввійшли два твори А. Гнатишина («Богородице Діво, радуйся» та «Вірую» $)^{52}$. «Божественну Літургію» у 2012 році записав камерний хор «Воскресіння» Катедрального собору св. Воскресіння УГКЦ в Івано-Франківську (регент - Володимир Рудницький), до якої включив «Благословенний, хто йде в ім'я Господнє» та «Відпуст» А. Гнатишина ${ }^{53}$. Чоловічий хор «Надія Церкви» Львівської Духовної семінарії Святого Духа, що заснований у 1991 році під керівництвом професора Володимира Головка, до свого CD включив твори А. Гнатишина («Блажен муж», «Тобою радується», «Чоловіче добрий», «Ангел сповіщав», «Радість 3 неба», «Царю небесний» (6 глас Київського розспіву), М. Федоріва («Христос воскрес») $)^{54}$. Камерний хор «Cantemus» церкви Царя Христа монастиря отців василіан 3 Івано-Франківська (регент -

${ }^{48}$ Ihor Sonevytsky. Liturhia i Panakhyda. L'vivs'kyi kamernyi khor GLORIA. CD, 2002.

49 «Хваліть ім’я Господнє». Церковний хор «Видубичі» 3 Києва (регент Володимир Віняр, диригент Зеновій Паламар). CD, 2003.

${ }^{50}$ Роман Гурко. «Літургія № 2». Церковний хор «Видубичі» 3 Києва (регент Володимир Віняр). CD, 2003.

${ }^{51}$ Камерний хор «Дзвони Подолу». Г. Китастий «Служба Божа» (диригент Тарас Миронюк). CD, 2003.

${ }^{52}$ «Багослови, душе моя, Господа». Камерний хор «Кредо» Катедрального собору св. Воскресіння УГКЦ в Івано-Франківську (регент - Жанна Зваричук). CD (початок 2000-х).

53 Камерний хор «Воскресіння» Катедрального собору св. Воскресіння УГКЦ в Івано-Франківську. «Божественна Літургія» (регент - Володимир Рудницький). CD, 2012.

54 Чоловічий хор «Надія Церкви». CD, 2005. 
заслужений діяч мистецтв України, кандидат мистецтвознавства Ігор Дем'янець) записав шість CD: «Божественна літургія» (служить о. Б. Ватащук) (2003), Духовні пісні» (2004), «Українське Різдво» (2005), Акафіст «Слава Богу за все», «Молебень до Пресвятої Богородиці» та «Молебень до Христа Чоловіколюбця» (служить єпископ Івано-Франківський Софрон Мудрий) (2009) ${ }^{55}$. До «Божественної Літругії» включено частини А. Гнатишина, до «Молебня до Пресвятої Богородиці» (2009) - «Молебень до Пресвятої Богородиці» А. Гнатишина, його аранжування твору «Просимо тя Діво». Колядка «Янголи в небі» в обр. О. Кошиця ввійшла до CD «Українське Різдво» (2005). Молодіжний хор «Осанна» церкви Царя Христа монастиря отців василіан з Івано-Франківська (регент - Люба Терлецька) до свого CD «Різдво-Коляда» включив колядки А. Гнатишина («Все в нас сьогодні»), О. Кошиця («Що то за предиво») та І. Недільського («На свят вечір») $)^{56}$.

\section{ВИСНОВКИ}

Отже, церковна музика композиторів української діаспори відіграла значну роль у відродженні національно-культурної і релігійної ідентичностей православної і греко-католицької церкви в сучасній Україні завдяки друку нотних видань композиторів діаспори в Україні, введенню творів композиторів діаспори до репертуару кафедральних та парафіяльних хорів української церкви та ї активному пропагуванню як у Богослужіннях, так і в концертно-фестивальній практиці в Україні та країнах Європи, а також широкому тиражуванню грамзаписів.

\section{АНОТАЦІЯ}

Церковна музика відомих композиторів української діаспори XX століття Олександра Кошиця, Михайла Гайворонського, Андрія

55 «Божественна Літургія. Хор «Cantemus» церкви Царя Христа монастиря отців василіан 3 Івано-Франківська (регент - Ігор Дем'янець). CD (б/p); «Молебень до Пресвятої Богородиці». Служить Владика Софрон Мудрий, ЧСВВ. Камерний хор «Cantemus» церкви Царя Христа монастиря отців василіан 3 Івано-Франківська (регент - заслужений діяч мистецтв України, кандидат мистецтвознавства Ігор Дем'янець); «Українське Різдво». Камерний xop «Cantemus» церкви Царя Христа монастиря отців василіан 3 ІваноФранківська. CD, 2005.

${ }^{56}$ Молодіжний хор «Осанна» церкви Царя Христа монастиря отців василіан з Івано-Франківська (регент - Люба Терлецька). «Різдво-Коляда». CD (б/p). 
Гнатишина, Григорія Китастого, Мирона Федоріва, Ігоря Соневицького, Зенона Лавришина та Романа Гурка відіграла важливу роль у відродженні національно-культурної і релігійної ідентичностей православної і греко-католицької церкви в сучасній Україні, оскільки завдяки жертовній праці цих митців було збережено традиції церковного співу, забороненого впродовж 70-ти років радянського атеїстичного режиму. Важливими джерелами відродження церковного співу в незалежній Україні спершу були нотні видання церковної музики, видані в діаспорі, а згодом - на рідній землі. Промоуторами цього процесу виступали хорові диригенти, регенти, які одночасно є викладачами мистецьких закладів. Вони активно вводили до репертуару очолюваних хорових колективів невідому духовну спадщину, виконуючи кілька функцій: збереження і пропагування цієї спадщини на рідних теренах, збагачення репертуару, формування національно-культурної і релігійної ідентичностей у хористів і слухачів, виховання студентської молоді мистецьких навчальних закладів на кращих зразках духовної музики композиторів діаспори, розширення комунікативного поля завдяки використанню засобів грамзапису, Інтернет-ресурсів.

Результати дослідження засвідчують, що використання церковної музики композиторів української діаспори сприяло відродженню національно-культурної і релігійної ідентичностей православної і греко-католицької церкви в сучасній Україні, духовному збагаченню українців, утвердженню вітчизняної хорової музики в європейському культурному просторі.

\section{ЛІТЕРАТУРА}

1. Воскресіння. Хорова родина. Нариси 3 історії хорового мистецтва / упоряд. О. Тарасенко. Рівне : О. Зень, 2011. 360 с.

2. Гелнер Е. Нації та націоналізм. Націоналізм / пер. 3 англ. Київ : Таксон, 2003. 300 с. (Ex professo).

3. Гібернау М. Ідентичність націй. Київ : Темпора, 2012. 304 с.

4. Карась Г. Музична культура української діаспори у світовому часопросторі XX століття : монографія. Івано-Франківськ : Тіповіт, 2012. $1164 \mathrm{c}$.

5. Кияк С. Ідентичність українського католицизму: генезис, проблеми, перспективи : монографія. Івано-Франківськ : Нова Зоря, 2006. 632 c. 
6. Козловець М.А., Ковтун Н.М. Національна ідентичність в Україні в умовах глобалізації : монографія. Київ : ПАРАПАН, 2010. 348 c.

7. Нагорна Л.П. Регіональна ідентичність: український контекст. Київ : ІПіЕНД імені І.Ф. Кураса НАН України, 2008. 405 с.

8. Сміт Е. Культурні основи націй. Ієрархія, заповіт і республіка. Київ : Темпора, 2009. 312 с.

9. Эриксон Э. Идентичность: юность и кризис / пер. с англ.; общ. ред. и предисл. А.В. Толстых. 2-е изд. Москва : Флинта, 2006. 352 с. (Библиотека зарубежной психологии).

\section{НОТОГРАФІЯ}

10. Благослови, душе моя, Господа: хорові твори 3 репертуару камерного хору «Кредо» кафедрального собору св. Воскресіння УГКЦ м. Івано-Франківська / упоряд Ж. Зваричук. ІваноФранківськ : Плай, 2010. 90 с.

11. Велика Субота і Пасха: партитура / ред., упор. Василь Завітневич. Нью-Йорк : Науково-Богословський ін-т УПЦ в США, муз. відділ, 1964. 207 с.

12. Вибрані хорові твори українських композиторів для Служби Божої. 3 репертуару камерного хору «Благовіст» / упоряд. 3. П. Яропуд, о. А. Федик. Кам'янець-Подільський : видавець П. П. Зволейко Д.Г. , 2017. 288 с.

13. Вінчання / зібрав і до тексту української народної мови приробив С. Чичула. Чікаго, 1976. 12 с. [Кафедральний хор «Славута». Мистецький керівник Юрій Яримович].

14. Всеношна: партитура, част.1: Вечірня / [ред. і упор. В. Завітневича] / Науково-Богословський інститут УПЦ в США, муз. відділ. Нью-Йорк, 1960. 264 с.

15. Всеношна: Партитура, част. 2: Утреня / [ред. і упор. В. Завітневича] / Науково-Богословський інститут УПЦ в США, муз. відділ. Нью-Йорк, 1961. 267 с.

16. Гайворонський М.О. Служба Божа Б-дур мішаний хор a cappella. Жовква : Видавництво і друкарня чина св. Василія В., 1938. $55 \mathrm{c}$.

17. Гнатишин А. Богородиці на славу: хорові твори a cappella. Відень, 1974. 41 с. Рукопис.

18. Гнатишин А. Божественна літургія: для триголосного хору a cappella: Kirchenslawisch. Deutsch, 1998. 141 c. 
19. Гнатишин А. Молебень до Христа-Чоловіколюбця - для мішаного хору а capella. Відень. $6 \mathrm{c}$.

20. Гнатишин А. Служба Божа: для мішаного хору a capella. Відень, 1965. 65 с. Рукопис.

21. Гнатишин А. Служба Божа - самолівкова; для мішаного хору a capella. Відень, 1985. 34 с. Рукопис.

22. Гнатишин А. Українські церковні пісні на всі свята для мішаного хору / передмова - о. Софрон Мудрий. Відень - Рим, $1986.113 \mathrm{c}$.

23. Гнатишин А. Хорові твори / ред.-упоряд. С. Дацюк. Дрогобич : Посвіт, 2010. 79 с.

24. Духовні композиції Михайла Гайворонського : навч.-метод. посібник / упоряд. А. Славич. Дрогобич : Посвіт, 2015.

25. Збірник Літургійних і Церковних пісен / упор. Андрій Ситник. Аделаїда, Австралія: B-во: Slavic Musoft, 1991. 94 с.

26. Збірник літургійних співів присвячений тисячоліттю Української православної церкви / зредагував і впорядкував Василь Завітневич. Бавнд Брук, Нью-Джерзі : Видання УПЦ в США, 1979. $467 \mathrm{c}$.

27. Китастий Г. Служба Божа. Нотна збірка для мішаного хору. Київ, 2006. 56 с. [Бібліотека хору «Дзвони Подолу»].

28. Кошиць О. Релігійні твори / за ред. Зіновія Лиська. НьюЙорк : УВАН у США, $1970.736 \mathrm{c.}$

29. Лавришин 3. Служба Божа. Літургія для мішаного хору / Зеновій Лавришин. Торонто, 1988. 64 с. [Б-ка української духовної музики. У пам'ять 1000-ліття Хрещення Руси-України].

30. Лавришин 3. Служба Божа на сопран, альт і бас. Торонто : Накладом автора, 1978. 27 с.

31. Літургії і Панахида на основі традиційних мотивів західніх українських земель на мішаний хор уложив Богдан Кушнір. [Детройт, США], [б. р.]. 138 с.

32. Літургічні пісні для чоловічого хору / зібрав і до тексту в українській народній мові приробив Степан Чичула, 2-ге вид. Чикаго, 1984. $88 \mathrm{c}$.

33. Літургічні пісні для чоловічого хору, част. 2 / зібрав і до тексту в українській народній мові приробив Степан Чичула, 6-е поширене вид. Чикаго, 1984. 136 с.

34. Літургічні пісні. Мішаний хор. Різні композитори. Служба Божа. Додаткові пісні до Служби Божої. Чин Вінчання. Чин Похорону. Воскресна Утреня. Пісні на сцену. Принагідні пісні / 
зібрав і до тексту в українській народні мові приробив С. Чичула. 4-е, дещо змінене вид. Шикаго, 1979. 240 с.

35. Літургія (скорочене видання) : збірка професора Івана Трухлого / ред. і видавець д-р В. Трухлий. Чикаго : Фундація Катерини Здорик, 1991. 260 с.

36. Літургія. Divine Liturgy. Капеля Бандуристів ім. Т. Шевченка (США). Нью-Йорк, 2003. 79 с.

37. Релігійні канти та псальми українського народу: на мішаний хор / аранжував О. Кошиць. Київ; Ляйпціг : Українська накладня, Б. p. 30 с. Вид-во «Україна». Ч. 53.

38. Свята Літургія Івана Золотоустого: вибрані хорові твори українських композиторів для Служби Божої. 3 репертуару камерного хору «Кредо» / упоряд. о. Ю. Новицький, Ж. Зваричук. Івано-Франківськ : Нова Зоря, 2009. 180 с.

39. Соневицький I. Духовні твори. Львів : Спілка композиторів України, 1999. 108 с.

40. Соневицький I. Літургія g-moll. Соневищький I. Духовні твори. Львів: Спілка композиторів України, 1999. С. 5-48.

41. Співи на Літургії: Партитура / ред. і упор. В. Завітневич / Науково-Богословський інститут УПЦ в США, муз. відділ. НьюЙорк, 1963. 399 с.

42. Співи Постової Тріоді: Партитура / ред. i упор. В. Завітневич / Науково-Богословський інститут УПЦ в США, муз. відділ, 2-ге вид. Бавнд-Брук, Нью-Джерзі, 1978. 196 с.

43. Федорів М. Велика Вечірня з Литією. У пам'ять 1000-ліття Хрещення Руси-України (988-1988) для мішаного хору. Філядельфія, 1986. 49 с.

44. Федорів М. Єрусалимська утреня у Велику П'ятницю на мішаний хор. Чікаго, 1971.48 с.

45. Федорів М. Срусалимська утреня (у Велику П'ятницю) на мішаний хор. 2-е вид. Філадельфія, 1982. 46 с.

46. Федорів М. Збірник літургічних співів Закарпатської Церкви Візантійського обряду для мішаного хору. Філядельфія, 1982. 108 с. [Із серії видань 3 підготовчого періоду для відзначення 1000-ліття християнства Руси-України (988-1988)].

47. Федорів Мирон М. Обрядові співи української церкви Галицької Землі. II ч. Літургійні співи. Філядельфія, ПА, 1983. 294 c.; 1989. 395 c.

48. Федорів M. Служба Божа F-dur для мішаного хору. Філядельфія, 1982. 30 с. 
49. Федорів М. Служба Божа для мішаного хору in G-dur. Подана за українським народним наспівом. Чікаго : Вид-во Єпархії св. О. Николая, 1967. 35 с.

50. Федорів М. Українські релігійні пісні на хори мішані, чоловічі й жіночі. Ч. І. Шікаго : Видання О.О. Василіян, 1960. 52 с.

51. Федорів М. Українські релігійні пісні на хори мішані, чоловічі й жіночі,сольові й інструментальні. Ч. ІІ. Шікаго : Видання О.О. Василіян, 1960. 55 с.

52. Федорів М. Церковні пісні для змішаного хору. І. Молебні пісні до Матері Божої. Львів : Вид-во Отців Василіян «Місіонер», 1995. $64 \mathrm{c}$.

53. Федорів М. Церковні пісні на мішаний хор. Репринтне видання. Львів, 2004. 36 с.

54. Федорів М. Церковні співи на три однорідні голоси (жіночі або чоловічі). Філядельфія : Видання сс. Василіянок, 1986. 105 с.

55. Федорів М. Частини до Служби Божої та інше на мішаний хор. Видання оо. Василіан, 1991. 100 с. [Із серії видань 3 підготовчого періоду для відзначення Тисячоліття Хрещення Руси-України (988-1988)].

56. Херувимська пісня України та іï діаспори. Антологія / упоряд. Г. Куземська, Д. Редчук. Київ : КЖД «Софія», видання парафії св. Архистратига Михаїла, Київ (Пирогів), 2010. 516 с.

\section{ДИСКОГРАФІЯ}

57. «Благослови, душе моя, Господа». Камерний хор «Кредо» Катедрального собору св. Воскресіння УГКЦ в Івано-Франківську (регент - Жанна Зваричук). CD (початок 2000-х).

58. «Божественна Літургія. Хор «Cantemus» церкви Царя Христа монастиря отців василіан 3 Івано-Франківська (регент - Ігор Дем'янець). CD (б/p).

59. До 2000-ліття Різдва Христового «Золоті сторінки української музики». Ансамбль солістів «Благовість». Духовна музика / диригент Мирослав Гулковський. Художній керівник Тетяна Кумановська.CD. 1997.

60. Камерний хор «Воскресіння» Катедрального собору св. Воскресіння УГКЦ в Івано-Франківську. «Божественна Літургія» (регент - Володимир Рудницький). CD, 2012.

61. Камерний хор «Дзвони Подолу». Г. Китастий «Служба Божа» (диригент - Тарас Миронюк). CD, 2003. 
62. «Молебень до Пресвятої Богородиці». Служить Владика Софрон Мудрий, ЧСВВ. Камерний хор «Cantemus» церкви Царя Христа монастиря отців василіан 3 Івано-Франківська (регент заслужений діяч мистецтв України, кандидат мистецтвознавства Ігор Дем'янець).

63. Молодіжний хор «Осанна» церкви Царя Христа монастиря отців василіан 3 Івано-Франківська (регент - Люба Терлецька). «Різдво-Коляда». CD (б/p).

64. Роман Гурко. «Літургія № 2». Церковний хор «Видубичі» 3 Києва (регент Володимир Віняр). CD, 2003.

65. «Українське Різдво». Камерний хор «Cantemus» церкви Царя Христа монастиря отців василіан з Івано-Франківська. CD, 2005.

66. «Хваліть ім’я Господнє». Церковний хор «Видубичі» з Києва (регент Володимир Віняр, диригент Зеновій Паламар). CD, 2003.

67. Чоловічий хор «Надія Церкви». CD, 2005.

68. Ihor Sonevytsky. Liturhia i Panakhyda. L'vivs'kyi kamernyi khor GLORIA. CD, 2002.

\section{Information about author:} Karas H. V.,

Doctor of Arts, Professor, Professor at the Department of Music Education and Conducting Methods Vasyl Stefanyk Precarpathian National University 57, Shevchenko Str., Ivano-Frankivsk, Ukraine 